\title{
Variability in the mass flux of the Ross ice streams, West Antarctica, over the last millennium
}

\author{
Ginny CATANIA, ${ }^{1,2}$ Christina HULBE, ${ }^{3}$ Howard CONWAY, ${ }^{4}$ T.A. SCAMBOS, ${ }^{5}$ \\ C.F. RAYMOND ${ }^{4}$ \\ ${ }^{1}$ Institute for Geophysics, University of Texas, Austin, TX, USA \\ E-mail: gcatania@ig.utexas.edu \\ ${ }^{2}$ Department of Geology, University of Texas, Austin, TX, USA \\ ${ }^{3}$ Department of Geology, Portland State University, Portland, OR, USA \\ ${ }^{4}$ Department of Earth and Space Sciences, University of Washington, Seattle, WA, USA \\ ${ }^{5}$ National Snow and Ice Data Center, University of Colorado, Boulder, CO, USA
}

\begin{abstract}
We synthesize previously published remote-sensing observations, radar data and model output to obtain a $\sim \mathbf{1 0 0 0}$ year ice flow history for the Siple Coast ice-stream system in West Antarctica to investigate the timing and magnitude of changes in mass flux. The synthesized history shows significant short-term variability in ice-stream shear margin and grounding line position due to internal variability of the coupled system. The chronology highlights the interplay between adjacent ice streams, which implies that the behavior of any individual ice stream should not be examined in isolation. Furthermore, individual events cannot be fully interpreted without an understanding of the broad-scale, long-term variability in the ice sheet. In the context of this millennium-scale history, we interpret the relatively recent stagnation of Kamb Ice Stream (KIS) as just one stage in the thermodynamic cycle of an ice stream in this region. The changes in mass balance that result from the KIS stagnation may thus be viewed as century-scale 'noise' relative to the longer-term trend. Understanding and characterizing this noise is a necessary step before accurate model-based predictions of ice-sheet mass balance for the next century can be made.
\end{abstract}

\section{INTRODUCTION}

Assessing the response of the Earth's glaciers and ice sheets to climate change is a primary goal of glaciological research. The West Antarctic ice sheet (WAIS) has received a great deal of attention because much of it is grounded below sea level with a landward sloping bed (Lythe and others, 2001; Bamber and others, 2009), making it more susceptible to rapid collapse through grounding line retreat (Weertman, 1974; Schoof, 2007). The Amundsen Sea sector of the WAIS is currently undergoing rapid and large changes in mass balance (Chen and others, 2009; Pritchard and others, 2009) owing to higher ocean temperatures at the termini of glaciers there (Thoma and others, 2008; Jenkins and others, 2010). While mass loss here appears to be externally forced by regional environmental changes, perturbations to the glacier termini can effectively access the ice-sheet interior through ice-dynamic mechanisms. Largely as a result of the loss of ice through the Amundsen Sea sector, the WAIS has a mass deficit of $132 \pm 26 \mathrm{Gta}^{-1}$ (Chen and others, 2009). In contrast, the Siple Coast region within the WAIS is currently in a phase of positive mass balance estimated to be $26.8 \pm 14.8 \mathrm{Gta}^{-1}$ (Joughin and Tulaczyk, 2002). While positive mass balance in this part of the WAIS is not sufficient to offset losses in other parts, the total mass gained in this region is equivalent to the measurement uncertainty in losses estimated from the Gravity Recovery and Climate Experiment (GRACE) for the entire WAIS (Chen and others, 2009). This suggests that we need to focus our efforts on both reducing the measurement uncertainty for satellite estimates of ice-sheet mass balance as well as improving our understanding of the timing and magnitude of the natural variability in mass changes in the system.
The current state of positive mass balance for the Siple Coast region is the result of the stagnation of Kamb Ice Stream (KIS; former Ice Stream C) (Retzlaff and Bentley, 1993) and the continued slowdown of Whillans Ice Stream (WIS; former Ice Stream B) (Joughin and others, 2005; Stearns and others, 2005) (Fig. 1). Such events fit within a larger framework of variability that characterizes the region (e.g. Fahnestock and others, 2000; Conway and others, 2002; Catania and others, 2006a; Hulbe and Fahnestock, 2007). The observed fluctuations in discharge that occur here are not coincident with external forcing but instead appear to result from internal variabilities in the ice-stream system which have been ongoing since at least the end of the Last Glacial Maximum (LGM) (Anderson and others, 2002; Mosola and Anderson, 2006; Dowdeswell and others, 2008).

It is important to quantify the timescales required for such changes in mass balance to occur and the impact of seemingly isolated changes in ice-stream configuration on the ice-stream system as a whole. In this paper, we synthesize previously published observations on the timing and magnitude of changes in ice-stream boundaries for the Siple Coast system in order to build a chronology of ice flow changes that span the last millennium. This chronology provides an improved understanding of the temporal and spatial scales involved in the observed variability for the region. In particular, we focus on KIS and WIS where many observations have been made and where the largest changes are observed.

\section{BACKGROUND: SIPLE COAST ICE STREAMS}

Retreat of the WAIS since the LGM has been rapid in regions drained by ice streams (Bindschadler, 1998) which 


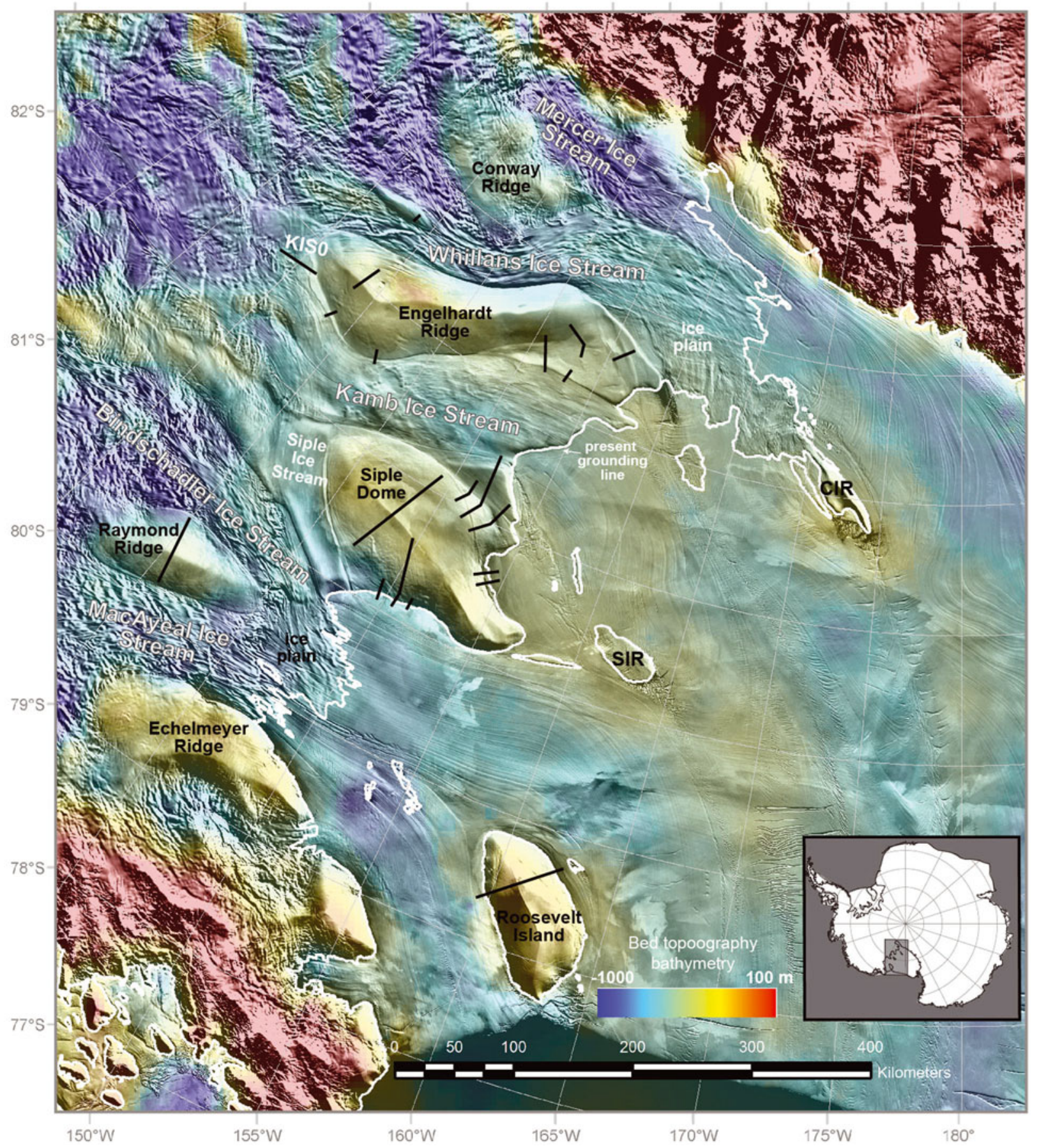

Fig. 1. MODIS Mosaic of Antarctica (MOA) over the Siple Coast ice streams (Haran and others, 2006; Scambos and others, 2007) with bed topography/bathymetry relative to mean sea level from LeBrocq and others (2010). The modern grounding line position (white line) is provided by Bohlander and Scambos (2007). Ice rises and inter-ice-stream ridges are labeled in black, with Steershead and Crary Ice Rises as SIR and CIR respectively. Radar data collected by prior studies but used in our chronology are indicated with black lines. Inset shows the region in context of Antarctica.

effectively evacuate ice from the ice-sheet interior. The Siple Coast ice-stream system consists of six fast-flowing ice streams which comprise the primary pathways for drainage of ice from the interior to the Ross Ice Shelf (Fig. 1). The ice streams have low surface slopes and, as a result, low driving stresses even though horizontal velocities of up to $\sim 800 \mathrm{~m} \mathrm{a}^{-1}$ are reached (Bentley, 1987). High flow speeds within these ice streams are maintained because their basal temperatures are at the pressure-melting point (Engelhardt, 2004) and the subglacial material is water-saturated clay (Anandakrishnan and others, 1998; Bell and others, 1998).
As a result, basal motion occurs through a combination of basal sliding and till deformation along the ice/bed interface (Blankenship and others, 1986; Engelhardt and others, 1990). The beds of ice streams are at slightly lower elevations than adjacent inter-ice-stream ridges under which basal freezing conditions prevail (Lythe and others, 2001; Engelhardt, 2004).

The WAIS evolved to its present form from a more horizontally extensive ice sheet that existed during the LGM (Bindschadler and Vornberger, 1998; Anderson and others, 2002; Stone and others, 2003); however, the Siple Coast ice 
streams likely maintained their thin, long, low-slope profiles (Ackert and others, 2007; Price and others, 2007) and remained approximately in their present locations (Anderson and others, 2001). Conway and others (1999) suggest that grounding line retreat since the end of the LGM occurred as a 'swinging gate', hinged near Roosevelt Island. According to their model, ungrounded conditions initiated at Roosevelt Island around $3 \mathrm{kaBP}$. Multiple grounding zone sediment wedges within the paleo-ice-stream troughs on the floor of the Ross Sea confirm that grounding line retreat was nonsteady and non-uniform across the region (Anderson and others, 2002; Mosola and Anderson, 2006). This picture aligns well with observations that suggest that modern icestream behavior is characterized by constant adjustment of discharge pathways. For example, KIS abruptly stopped 165 years ago (Retzlaff and Bentley, 1993), WIS and MacAyeal Ice Stream (MaclS; former Ice Stream E) have undergone stagnation and reactivation cycles (Hulbe and Fahnestock, 2007) and the boundaries of ice streams (both lateral margins and grounding lines) are shifting through time (e.g. Clarke and others, 2000; Stearns and others, 2005; Catania and others, 2006b, 2010).

The tributaries of the Siple Coast ice streams reach far into the interior of the ice sheet (Joughin and others, 1999) and feed ice toward their trunk regions where, in some cases, an ice plain forms. Ice plains are regions where an ice stream transitions from fully grounded to fully floating conditions over many tens of kilometers through a gradual reduction in basal drag along the flow direction (Alley and others, 1989). Two modern ice plains exist in the Siple Coast system. A small one exists on MacIS (Anandakrishnan and others, 2003) and a much larger one occupies the combined outflow region of WIS and Mercer Ice Stream (MIS; former Ice Stream A) (Fig. 1; Bindschadler and others, 2005; Brunt and others, 2010). Ice motion on the WIS/MIS ice plain is characterized by stick-slip behavior as a result of resistance from the subglacial till, paced by tidal forcing (Anandakrishnan and Alley, 1997; Bindschadler and others, 2003) and may be an attribute that emerges as ice streams decelerate (Sergienko and others, 2009). The trunk region of WIS is slowing by nearly $4 \mathrm{~m} \mathrm{a}^{-1}$ (Joughin and others, 2005) and thickening by $0.06 \pm 0.02 \mathrm{~m} \mathrm{a}^{-1}$ (Smith and others, 2005). If this trend continues, WIS will stagnate by the next century (Joughin and others, 2005). An ice plain is thought to have once existed in the mouth of KIS in the past (Joughin and others, 2002; Hulbe and Fahnestock, 2004; Catania and others, 2006a), but its extent and history have not been well constrained.

Ice streams thin along their lengths, causing a steepening of the basal temperature gradient along the flow direction, a process that can lead to freezing of basal water and a concurrent increase in basal resistance followed by slowdown and thickening (Christoffersen and Tulaczyk, 2003; Hulbe and Fahnestock, 2004). Local reduction of basal lubrication can produce variability in the ice-stream system (Tulaczyk and others, 2000). Currently, the tendency toward freezing in the trunk regions of the Siple Coast ice streams is offset by a supply of water produced in the onset regions which provides sufficient latent heat to maintain thawed conditions at the base of the ice streams (Joughin and others, 2003; Parizek and others, 2003; Hulbe and Fahnestock, 2004). The amount of meltwater production suggests that they will continue to thin, resulting in continued grounding line retreat for the foreseeable future (Parizek and others, 2003).

\section{REVIEW OF PREVIOUS OBSERVATIONS}

We present a review of previously published observations of past configurations of the Siple Coast ice streams for the last 1000 years. Where dates are given in previously published work, we correct for the time since data acquisition (if available) or the time since publication (Table 1) in order to present a consistent time frame for all presented data. This gives dates in terms of time elapsed since year AD 1. While we present a chronology of events at specific dates (to the year) for ice flow changes, we do not infer that our timing of events is this precise. The dates are merely meant to serve as time markers that allow us to construct the chronology (Figs 2 and 3).

\section{Satellite imagery}

The first visible-band satellite images (Advanced Very High Resolution Radiometer (AVHRR), Système Pour l'Observation de la Terre (SPOT) and Landsat) of the Ross ice streams revealed complex surface lineations consisting of flow stripes, active and paleo-shear margins and the slope break associated with grounding lines and relict flow boundaries (Scambos and Bindschadler, 1991). Lateral flow boundaries to ice streams (shear margins) can be identified in satellite images by the presence of crevasses. Paleo-shear margins (shear margins buried by years of accumulated snow) remain visible in satellite images (e.g Moderate Resolution Imaging Spectroradiometer (MODIS)) (Fig. 1; Haran and others, 2006) because of enhancement through image stacking. Paleo-shear margins are, however, difficult to identify on the ground because they typically have amplitudes of a few meters and wavelengths of several kilometers (Catania and others, 2003, 2005).

Flow stripes occur in fast-moving regions and originate either from fast flow over bed bumps (Gudmundsson and others, 1998) or flow extension in onset regions (Glasser and Gudmundsson, 2011). Comparison of the character of the surface topography within regions of rapid flow and those with slow-moving ice reveals the presence of paleo-ice streams: regions that were once flowing fast but are now stagnant. Such regions are characterized by muted flow stripes and lateral 'scar' features marking the presence of buried shear margins (Scambos and Bindschadler, 1991; Scambos and Nereson, 1995). Jacobel and Gades (1995) and Conway and others (2002) used the presence of these muted surface features to identify a relict tributary to KIS and Siple Ice Stream (SIS), a distributary to KIS (Fig. 1). Paleoshear margins of these and other stagnant ice streams, most notably KIS, mark their lateral extent (Scambos and Nereson, 1995; Anandakrishnan and others, 2001).

Fahnestock and others (2000) used flow stripes and rifts visible in AVHRR images coupled with the Ross Ice Shelf Geophysical and Glaciological Survey (RIGGS) ice-shelf velocity field (Thomas and others, 1984) to determine when features visible in satellite images were formed by tracing their provenance. From this, they deduced large changes in ice-stream discharge and configuration throughout the last 1000 years, including evidence for the shutdown of KIS $\sim 165$ years ago (AD 1837), grounding of Steershead Ice Rise $\sim 350$ years ago (AD 1650) and the reduction in discharge of WIS relative to MIS $\sim 550$ years ago (AD 1450). We summarize their major findings in Table 1.

A new picture of ice-stream configuration emerged when RADARSAT mapped surface velocities in the Siple Coast 
Table 1. Previously published observations of ice-stream variability used in our chronology. Events are grouped into time periods identified in the text corresponding to Figures 2 and 3. For each event we give the time of the event in years BP, accounting for time passed since original publication and the approximate year that the event occurred

\begin{tabular}{lcc}
\hline Event & Time & Date (AD) \\
years BP & Source
\end{tabular}

\section{Fig. 2a:}

South Crary Ice Rise grounds

Fig. 2b:

KIS grounding line retreat

WIS turns off

MaclS stagnation

Fig. 2c:

MaclS reactivation

North Crary Ice Rise grounds

WIS and MIS flow north of Crary

Fig. 2d:

WIS restarts

KIS grounding line readvances

SIS turns off

Ross Ice Shelf grounding line in place

Fig. 3a:

Siple Dome grounding line in place

Steershead Ice Rise is formed

KIS narrows

MacIS and BIS speed up

Fig. 3b:

KIS tributary stagnates

Fig. 3c:

WIS upstream margin migration

KIS trunk shuts down

Inward migration of WIS margin

Fig. 3d:

KIS grounding line retreats

Ice thickness bulge grows at UpC

Lateral spreading of KIS bulge
1120

840-940

850

800

650

600

550

450

440

420

400

200-400

350

350

350

250

190

165

165

Modern

Modern

Modern
890

1067-1167

1157

1207

1357

1410

1450

1557

1567

1582

1607

1607-1807

1650

1652

1652

1750

1803

1837

1837

N/A

N/A

N/A
Bindschadler and others (1990)

Catania and others (2010)

Hulbe and Fahnestock (2007)

Hulbe and Fahnestock (2007)

Hulbe and Fahnestock (2007)

Bindschadler and others (1990)

Fahnestock and others, (2000)

Hulbe and Fahnestock (2007)

Catania and others (2010)

B. Smith (personal communication, 2010)

Catania and others (2010)

Catania and others (2010)

Fahnestock and others (2000)

Catania and others (2006b)

Hulbe and Fahnestock (2007)

Conway and others (2002)

Clarke and others (2000)

Retzlaff and Bentley (1993)

Catania and others (2006b)

Catania and others (2003)

Thomas and others (1988)

Price and others (2001)

Smith and others (2005) sector for the first time (Joughin and others, 1999). These data revealed an inland network of tributaries that connect ice streams in their upper catchment regions, even for KIS despite a stagnant trunk. In addition, the RADARSAT data have been used in conjunction with older satellite imagery (and other datasets) to discover a reduction in the speed of WIS (Joughin and others, 2003; Stearns and others, 2005) suggesting its eventual shutdown in AD 2150 (Joughin and others, 2005).

\section{Satellite altimetry}

Detailed mapping of surface elevation changes is accomplished using satellite altimeters. Repeat-track analysis of surface elevation data determined by NASA's Ice, Cloud and land Elevation Satellite (ICESat) has been used to identify the position of, and changes in, the grounding line (Fricker and Padman, 2006; Horgan and Anandakrishnan, 2006; Brunt and others, 2010). Comparison to previous grounding line position estimates indicates that the grounding line has not migrated significantly in the last few decades (Horgan and Anandakrishnan, 2006), although rates of retreat of up to $\sim 400 \mathrm{~m} \mathrm{a}^{-1}$ have been measured along some parts of the WIS grounding line (Bindschadler and Vornberger, 1998; Fricker and Scambos, 2009; Brunt and others, 2010). ICESat repeat- and cross-track analysis for ice-sheet thickness changes shows thinning throughout most of the region with the exception of the KIS tributary region and the WIS trunk, where thickening is occurring (Smith and others, 2005; Pritchard and others, 2009). These studies suggest that changes occurring in this region are ongoing.

Satellite-derived observations of localized surface elevation changes have also led to the discovery of rapidly draining and filling subglacial lakes through repeat-track observations of localized elevation changes (e.g. Gray and others, 2005; Wingham and others, 2006; Fricker and others, 2007; Stearns and others, 2008; Fricker and Scambos, 2009). Such observations reveal that the residence times for water in these lakes can be short (months to years) and that lake systems may be connected (drainage in one lake often results in filling of another lake at a lower hydraulic potential). The impact on ice flow speed has only been observed for Byrd outlet glacier (Stearns and others, 2008) which experienced a $10 \%$ increase in speed over a 14 month time period that was well timed with the drainage of a lake into the Byrd Glacier subglacial drainage system.

\section{Ice-penetrating radar data}

While the record of ice-sheet change can be readily observed in satellite images, the timing of past changes 


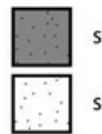

streaming ice (floating) slow-moving ice (floating)
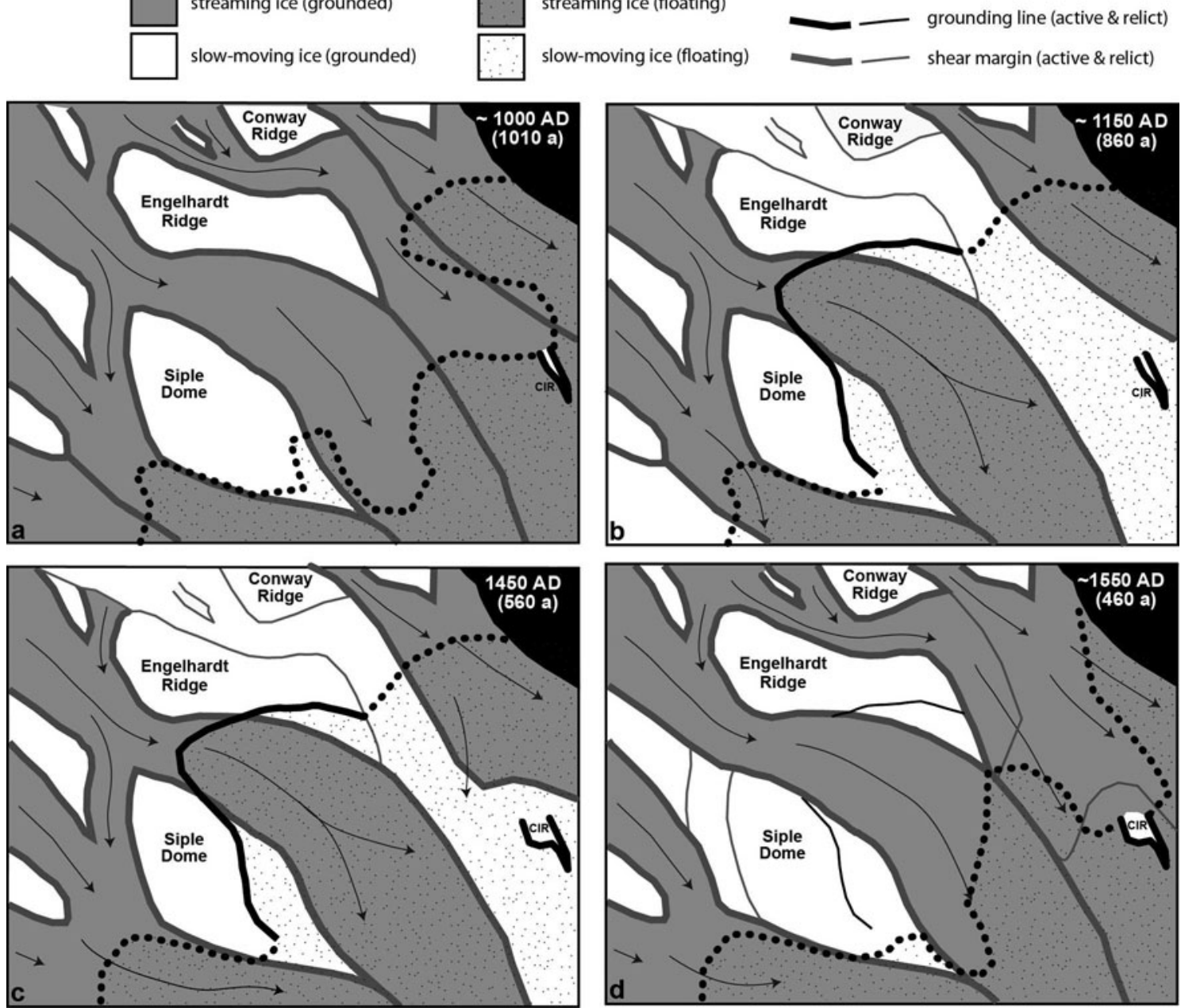

Fig. 2. Changes in the Siple Coast ice streams from (a) AD 1000 to (b) AD 1150 to (c) AD 1450 to (d) AD 1550. Fast-moving ice is colored dark gray, slow-moving ice is white and floating ice is overlaid with dots. Lines denote ice-dynamic boundaries, shear margins and grounding lines; known position is given as a solid line, and unknown is dotted. Active boundaries are plotted with thick lines, and inactive boundaries marking the presence of a modern-day surface scar are shown as thin lines. Arrows indicate flow direction and migration direction of margins.

remains uncertain without additional information. Icepenetrating radar data make visible the internal stratigraphy of ice sheets and have been used extensively to interpret and date historical changes in ice flow dynamics (e.g. Rippin and others, 2003, 2006). This is typically accomplished using radar data collected over paleo-ice-stream shear margins. Shear-margins are characterized by multiple crevasse-ridden zones with both chaotic and organized patterns of crevassing (Echelmeyer and others, 1994). In radar, paleo-shear margin crevasses are identified as hyperbolic diffractors that occur at a burial depth related both to the accumulation rate and the timing of crevasse closure (which is assumed to be synchronous with ice-stream shutdown). The timing of the shutdown of KIS was determined to be $\sim 165$ years BP, in AD 1837 (Retzlaff and Bentley, 1993; Catania and others, $2006 \mathrm{~b})$, based on an accumulation rate of $0.058 \mathrm{~m} \mathrm{a}^{-1}$ and a crevasse burial depth of $18 \mathrm{~m}$. Additional shear margins have been dated using similar techniques (Clarke and others, 2000; Conway and others, 2002; Smith and others, 2002; Catania and others, 2005, 2006b). Timing estimates for icestream marginal changes from these studies (Fig. 1) are listed in Table 1. Typical error estimates for dating shear margins are about $10 \%$ of the age, which accounts for the change in radar-wave travel times in the firn column.
Grounding lines are identified in radar-derived stratigraphy by the presence of basal crevasses (Uratsuka and others, 1996; Catania and others, 2010) and in some cases by the formation of locally downwarped internal layers due to sub-ice-shelf basal melting (Catania and others, 2006a, 2010; Smith, 1996). Using the degree of layer downwarping and expected rates of basal melting, the duration of ungrounded conditions can be estimated, as has been done for several grounding line locations in our study region (Catania and others, 2010). Their results indicate that the KIS grounding line migrated $\sim 100 \mathrm{~km}$ inland roughly between AD 1067 and AD 1167 and advanced toward its present location $\sim 440$ years later (AD 1567). Additional data from the north side of Siple Dome and the south side of Roosevelt Island indicate that the grounding line has been in its present location since between AD 1607 and 1807 and since AD 1607 respectively (Catania and others, 2010). Dates from these studies are summarized in Table 1, with their radar data collection locations shown in Figure 1. Significant uncertainty exists for these grounding line ages owing to the lack of knowledge of past grounding line melt rates, so Catania and others (2010) argue that their date estimates are maxima.

The formation and longevity of ice rises (Fig. 1) may also be used to constrain grounding line history. Three prominent 

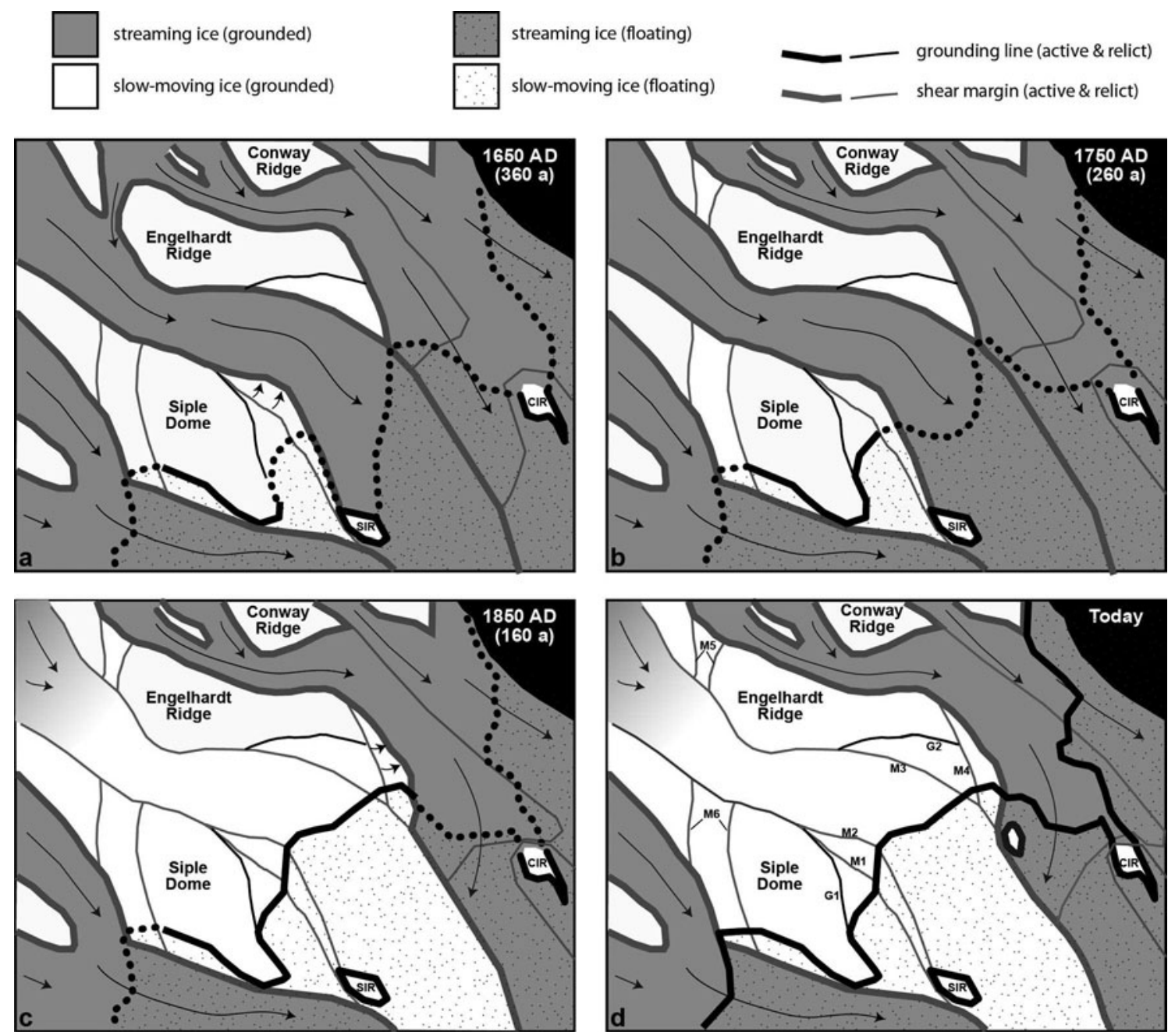

Fig. 3. Same as Figure 2, but from (a) AD 1650 to (b) AD 1750 to (c) AD 1850 to (d) present day.

ice rises exist in the Ross Ice Shelf: Roosevelt Island, Crary Ice Rise and Steershead Ice Rise. Radar-derived ice-sheet stratigraphy across Roosevelt Island indicates that the ice divide here formed $\sim 3200$ years ago (1190 BC), implying that the grounding line was upstream of this island until that time (Conway and others, 1999). We assume that at this time the grounding line was everywhere upstream of Roosevelt Island. Two deep borehole temperature records were used by Bindschadler and others (1990) to establish that Crary Ice Rise grounded in two stages: the north side becoming grounded 600 years ago, in AD 1410, while the southern side grounded earlier, $\sim 1120$ years ago (AD 890). Analysis of flow stripes and crevasse patterns around Steershead Ice Rise suggests that it grounded more recently, in AD 1650 (Fahnestock and others, 2000). These results are summarized in Table 1.

Ice-penetrating radar data have also been used to interpret long-term regional changes in mass balance through examination of ice-sheet divide migration of interice-stream ridges. Nereson and others (1998) found that the position of an ice-sheet divide straddled by ice streams will be sensitive to the discharge through those ice streams and the spatial distribution of accumulation. Discounting changes in accumulation as a driver of divide migration, Nereson and Raymond (2001) examined inter-ice-stream ridges throughout the Siple Coast region and found that all of the ice divides there showed northward migration, suggesting progressively higher rates of thinning across the Siple Coast region from MaclS toward WIS, with the most thinning occurring in the last 1000 years at WIS. This is in agreement with modern rates of enhanced thinning from ICESat on WIS (Pritchard and others, 2009).

\section{Ice flow models}

Ice-sheet models have been used to explore ice-sheet variability in the Siple Coast region. Ice-stream discharge variability results, in part, because of the existence of closely spaced bedrock troughs that direct ice flow and force competition for ice between adjacent ice streams (Payne and Dongelmans, 1997; Payne, 1998). Variability also arises because ice streams run just on the verge of shutting down all of the time (Hulbe and Fahnestock, 2004). This is because ice-stream discharge is thermally regulated, and involves basal meltwater interaction with subglacial till (MacAyeal, 1992; Payne, 1998; Tulaczyk and others, 2000; Bougamont and others, 2003). Using observational data of past flow variations to constrain and validate their numerical ice flow model, Hulbe and Fahnestock $(2004,2007)$ were able to reproduce the distorted streak lines preserved on the Ross Ice Shelf (Fig. 1) by forcing changes in ice-stream mass flux and ice-rise formation to find the best match to the observed streak-line patterns. Their solution was found when WIS and MacIS experienced periods of prolonged stagnation, and we use their estimates for the timing of ice-stream shutdown and 
reactivation for these ice streams in Table 1 . In addition, because the grounding line in the model studies of Hulbe and Fahnestock (2007) was determined by flotation, changes in ice thickness during their observational period will drive changes in the position of the grounding line and allow a rough history of grounding line position to be determined (Figs 2 and 3).

\section{RESULTS: ICE-FLOW CHRONOLOGY}

We use the observations described above to assemble a chronology of events (Table 1) that have occurred in the Siple Coast region over the last 1000 years. This chronology allows us to depict the most significant changes that have occurred in this region over that time period (Figs 2 and 3). We have grouped observations into time periods that break up the major reorganizational events occurring in the region. This results in time periods (described below) of differing length. Since we only have limited information about the position of ice-stream margins and grounding lines at very specific times and locations, we must infer their positions over time between known locations. In general, we use the grounding line position from Hulbe and Fahnestock (2007) who determine its position from flotation. Although we do not have information on elevation changes over the region until quite recently, we augment known grounding line position with inferred grounding line position based on expected thickness changes resulting from changes in ice flow through time. For example, during WIS stagnation between AD 1150 and 1557, we infer that ice streams on either side expanded laterally into the region from which WIS flowed. This expansion would allow for thinning of ice in these adjacent ice streams and possible grounding line retreat. The inferred grounding line position is shown as the dotted grounding line in Figures 2 and 3. More certain grounding line position information is provided by radar data and is shown by the solid grounding line in Figures 2 and 3.

Similar to the grounding line, we have only limited information about the position of ice-stream shear margins in the past. We assume that margin migration could occur in jumps, following Retzlaff and Bentley (1993) and Catania and others (2006b). We further assume that the shape of paleo-shear margins in plan form represents their shape and lateral extent when the ice streams were once active. This allows us to depict changes in the positions of shear margins in Figures 2 and 3. Uncertainty in dates from ice-penetrating radar data is $10 \%$ of the estimated age. No uncertainty estimates are given for dates provided in model or satellite studies, so we are not able to provide those here.

\section{Period 1: AD 1000-1207}

For convenience, we assume that all of the major ice streams were fast-moving at the beginning of this time period. We also assume that distributary SIS and tributary KISO were active and that KIS was at its widest extent (Fig. 2a). We approximate the grounding line position using the model results from Hulbe and Fahnestock (2007) and evidence that the southern edge of Crary Ice Rise grounded in AD 890 (Fig. 2a; Bindschadler and others, 1990). Both WIS and MaclS stagnated within $\sim 50$ years of each other near $\mathrm{AD}$ 1150, marking the end of this period (Fig. 2b; Hulbe and Fahnestock, 2007).

\section{Period 2: AD 1207-1557}

The shutdown of WIS had a dramatic impact on KIS and MIS. KIS experienced $\sim 100 \mathrm{~km}$ regression of its grounding line (Fig. 2b) occurring either coincident with or just after WIS stagnation (Catania and others, 2010). Grounding line retreat over such a short period must be a consequence of thinning, likely a result of lateral spreading across the confluence region of KIS, WIS and MIS due to the shutdown, and thus reduced outflow, of WIS. In addition to the observed grounding line retreat of KIS, we also expect grounding line retreat across the MIS/WIS ice plain after WIS shutdown (Hulbe and Fahnestock, 2007).

During this time period, Crary Ice Rise expanded to the northeast (Bindschadler and others, 1990), possibly as a result of local changes in basal water supply due to the initial freeze-on of its southern side (Fig. 2c). The growth of Crary Ice Rise may have further delayed the reactivation of WIS by continuing to block its outflow. Streaming flow from MIS continued to push the stagnant WIS ice around the northeastern side of Crary Ice Rise, producing a large distortion in the streak lines, which are still visible on the Ross Ice Shelf (Fahnestock and others, 2000; Hulbe and Fahnestock, 2007). The reactivation of WIS in AD 1557 marks the end of this period (MaclS, which shut down in AD 1207, reactivated in AD 1357 (Hulbe and Fahnestock, 2007)).

\section{Period 3: AD 1557-1837}

With the reactivation of WIS, outflow from KIS became laterally constrained causing thickening, which was likely responsible for the rapid, widespread grounding line advance that occurred throughout the KIS trunk at this time. Catania and others (2010) dated the seaward migration of the KIS grounding line at AD 1567, just 10 years after the WIS reactivation (Fig. $2 \mathrm{~d}$ ). With uncertainty in age estimates, these events may be viewed as synchronous. Retreat of the southern edge of Roosevelt Island grounding line to its modern position occurred in AD 1607 (Catania and others, 2010), roughly 400 years after the stagnation of MacIS. The southern grounding line of Roosevelt Island is currently downstream of the northern shear margin of MaclS and we estimate that it would have taken $\sim 400$ years for the effects of the MaclS stagnation (which would have led to localized thinning) to reach Roosevelt Island where it would have caused grounding line retreat (assuming an average icestream speed of $\sim 500 \mathrm{~m} \mathrm{a}^{-1}$ ).

The KIS distributary, SIS, shut down in AD 1582 (personal communication from B. Smith, 2010) after grounding line readvance of KIS (Fig. 2d). Shortly after the SIS shutdown, the grounding line along the northern edge of Siple Dome retreated to its modern location (Catania and others, 2010), consistent with the idea that thinning occurs in regions adjacent to locations of ice-stream shutdown (Hulbe and Fahnestock, 2007).

The northern KIS shear margin position jumped inward in AD 1652, 100 years after the KIS grounding line readvance (Catania and others, 2006b). This event isolated a triangularshaped region of ice adjacent to Siple Dome often called the 'Duckfoot' (Fig. 3a). Because the southern margin of KIS has been stable in its present location for several hundred years (as evidenced by a continuous streak line on the Ross Ice Shelf; Fahnestock and others, 2000), Catania and others (2006b) conclude that inward migration of the northern margin led to narrowing and a subsequent reduction in KIS 
discharge. Steershead Ice Rise formed coincident with KIS narrowing (Fahnestock and others, 2000). Ice-rise formation may have caused a regional reorganization of flow that, in turn, drove the migration of the northern KIS margin. These changes in the trunk region of KIS were quickly followed by the shutdown of tributary KISO in AD 1750 (Fig. 3b) (Conway and others, 2002).

\section{Period 4: AD 1837 to present}

The entire downstream trunk of KIS stagnated rapidly in AD 1837 (Retzlaff and Bentley, 1993), coincident with a minor inward shift of the WIS northern margin (Fig. 3c; Fahnestock and others, 2000; Catania and others, 2003) and inward migration of the southernmost WIS tributary (Clarke and others, 2000). With the stagnation of KIS, the supply of ice to the ice shelf is reduced and grounding line retreat near KIS is inevitable. At the time of the RIGGS surveys, the northernmost portion of the KIS grounding line was retreating at a rate of $30 \mathrm{~m} \mathrm{a}^{-1}$ (Thomas and others, 1988). Modern grounding line retreat rates for most of this region are currently very small (Horgan and Anandakrishnan, 2006), suggesting that the grounding line might retreat in jumps as observed in the past. This idea is supported by the presence of grounding zone sediment wedges on the Siple Coast floor which indicate that grounding line retreat was sporadic (Mosola and Anderson, 2006; Dowdeswell and others, 2008).

Active tributaries continue to feed into the upstream end of the stagnant KIS trunk, causing thickening in the transition region between active and stagnant flow regimes (near the junction between the KISO tributary and the KIS trunk; Fig. 1). Thickening occurs at a maximum rate of $0.5 \mathrm{~m} \mathrm{a}^{-1}$ but extends upstream into the tributaries at rates of 0.26 $0.29 \pm 0.03 \mathrm{~m} \mathrm{a}^{-1}$ (Smith and others, 2005) and has resulted in diversion of flow toward the upper regions of adjacent WIS and Bindschadler Ice Stream (BIS; formerly Ice Stream D) (Price and others, 2001). At the junction between the bulge and the stagnant trunk of KIS, driving stress and the hydraulic gradient must both be increasing over time as the bulge area thickens and the surface slope at the junction increases (Price and others, 2001).

At present, WIS is slowing at a rate that is expected to cause complete stagnation in $70-80$ years (Joughin and others, 2002; Stearns and others, 2005). From 1942 to 1998 the WIS ice plain was thinning (Bindschadler and others, 2005), but more recent observations from 2003 to 2005 show that it is now thickening (Smith and others, 2005; Pritchard and others, 2009). In addition to slowing and thickening, WIS is exhibiting modulated outflow according to the tidal cycle (Bindschadler and others, 2003). These observations may signal that WIS has already begun to make way for KIS reactivation; thickening and stick-slip behavior likely result from increased basal resistance (Sergienko and others, 2009). This is consistent within our framework of ice-stream cyclicity and the bimodal behavior of WIS and KIS (Payne, 1998).

\section{DISCUSSION}

Theoretical switches between fast and slow ice-stream motion have been reproduced in numerical ice-sheet models (MacAyeal, 1992; Payne and Dongelmans, 1997; Payne, 1998; Tulaczyk and others, 2000; Bougamont and others, 2003; Hulbe and Fahnestock, 2007) and are supported in our chronology. Proposed mechanisms for such switches involve thermodynamics at the ice-till interface, competition for ice in the upstream catchment, and interaction across the ice plain at the downstream ends of ice streams. Hulbe and Fahnestock (2004) identified icestream discharge cycles related to thermal instabilities that consist of an initial stage of fast thinning through the trunks of ice streams, promoting basal freeze-on and stoppage. Our chronology supports the thermal regulation hypothesis as there are no definitive events that occur prior to ice-stream shutdown that might cause shutdown to occur. One exception to this is KIS, which narrowed prior to shutdown. Narrowing causes a reduction in velocity that could exacerbate the loss of lubrication through a further reduction in basal shear heating (Catania and others, 2006b). Downstream of the grounding line, there is an infinite water supply; however, thinning can cause local bed obstructions to emerge as ice rises that, in turn, cause redirections of icestream flow that imprint on the streak-line record. We observe that the formation of ice rises precedes or is coincident with changes in ice-stream width (Figs 2 and 3).

Our chronology does not demonstrate a great amount of connectivity across ice streams in their catchment regions, although we have limited observations in those regions. We do observe a large amount of ice-stream interaction across their downstream reaches. In particular, changes in WIS and KIS appear to be intimately linked. Regions without large ice plains (e.g. MaclS and Echelmeyer Ice Stream (former Ice Stream F)) and where ice flow is typically bedrockcontrolled (e.g. Ronne-Filchner ice streams) do not show as much flow variability as WIS and KIS. This suggests that the particular bed topography of this region may permit ice plains to exist. Bathymetric data below the Ross Ice Shelf are sparse but indicate shallowing downstream of the modern grounding line around Siple Dome, KIS and WIS (Fig. 1). Any ice plain that developed in the mouth of KIS, as well as the modern WIS ice plain, would be characterized by flat surface topography. Local transients in ice thickness and surface slope on the ice plains might propagate laterally across them, allowing for the observed interaction between WIS and KIS.

In addition to total shutdown, we find that numerous changes in ice-stream configuration (shear margin and grounding line migration) also influence discharge over decadal to century timescales. Our reconstruction indicates that changes in discharge typically occur quickly. For example, the narrowing of KIS occurred in $\sim 10$ years (Catania and others, 2006b). Such rapid changes in margin position are due to rapid changes in the amount or distribution of basal lubrication, likely a result of basal freeze-on. It may also be possible that rapid changes in margin position could occur in conjunction with changes in the flux of water through the drainage/filling of subglacial lakes. The acceleration of Byrd Glacier due to upstream subglacial lake drainage might be expected, given that it is confined within the boundaries of the Transantarctic Mountains. The ice streams throughout Siple Coast also have many subglacial lakes beneath them (Gray and others, 2005; Fricker and others, 2007; Fricker and Scambos, 2009), but because the lateral boundaries of these ice streams are not as topographically controlled, the movement of subglacial water may alter the distribution of basal lubrication, thus promoting jumps in margin position, rather than gradual migration. This would be especially true for those 
lakes situated close to the active shear margins (on WIS, this is the case for most of the observed subglacial lakes), but recent observations indicate that significant meltwater is generated within the ice-stream shear margins (Beem and others, 2010).

We also observe fluctuations in the position of the grounding line at a time period when regionally steady grounding line retreat is expected (e.g. Conway and others, 1999). To some degree we may gain insight into grounding line variability by examining shoreline variability within experimental fluvial-deltaic systems where timescales for change are much shorter. In such systems the shoreline position is dictated by a combination of externally forced parameters, like sea level, and internal variability in the sediment supply from the channel system (Kim and others, 2006). In flume experiments Kim and others (2006) found greater rates of variability in the shoreline position during periods of forced shoreline retreat. This occurs because the shoreline is migrating against the sediment transport regime. An analogy may be made to ice-sheet grounding lines where, over short timescales, ice supply (influencing thickness) dictates the position of the grounding line; a steady supply of thick ice emerging from the ice streams acts against imposed grounding line retreat. We suggest that the observed variability in discharge may be typical during the retreat phase of the ice sheet. Further confirmation of this is the presence of sediment wedges that form along some portions of the grounding line (Anandakrishnan and others, 2007) that may act to temporarily stabilize parts of the grounding line against retreat (Alley and others, 2007). The presence of several grounding zone wedges within the paleo-ice-stream troughs confirms that during periods of sealevel rise, grounding line retreat is not steady (Mosola and Anderson, 2006). Our reconstruction confirms that grounding line retreat, at least for KIS, is episodic and punctuated by periods of advance.

\section{CONCLUSIONS}

The Siple Coast ice streams have undergone changes in configuration and discharge that are documented in many previous studies. We compile the observations from these past studies to assemble a chronology of ice-stream reorganizational events (Table 1; Figs. 2 and 3). Our reconstruction of ice flow history confirms that discharge cycles are typical for ice streams in this region. These discharge changes occur as a result of changes in ice-stream margin and grounding line positions as well as complete icestream shutdown, which is observed for three of the ice streams in this region over our 1000 year history. In part, flow variability here occurs because of the high degree of interaction between adjacent ice streams in their trunk/iceplain regions (likely because of shallow bed topography) but also because of changes in the distribution and supply of basal meltwater (either due to changes in subglacial lakes or because of basal freeze-on), causing local reductions in traction which can lead to shutdown. Downstream of the grounding line, thinning causes ice rises to emerge which locally block or redirect ice-stream outflow. Our observations provide a validation dataset for further modeling of ice flow in this region.

The WIS/KIS region has long been the focus of ice-stream variability studies and previous work focused on the apparently unique shutdown of KIS. Our reconstruction indicates that other ice streams (and their tributaries and distributaries) also experience stagnation, reactivation and margin migration. Further, ice-stream shutdown cannot be examined as an isolated event. We suggest that shutdown of individual ice streams should be expected in a system where small-scale, short-term variability is common despite the stability of the overall channel network pattern (and discharge), similar to fluvial systems. Ice-stream shutdown can have a pronounced effect on the short-term mass balance for this part of Antarctica (Joughin and Tulaczyk, 2002) and we advocate that future estimates of mass balance take into account the timescales for change in this region: discharge changes occur on approximately decadal to century timescales which are similar to timescales for mass-balance projections. As a whole, the Siple Coast icestream system is adjusting to changes in both external (climate-driven) and internal (thermodynamic-driven) forces. As a result, predictions of mass balance that only take into account the effects of one or two ice streams, or those that calculate mass balance over a short time period may mislead future estimates. In order to understand how mass balance might change in the future, thermomechanical ice flow models must begin to incorporate the possibility of rapid icestream stagnation and the unique physics represented by ice plains and grounding lines. Predictive models of Antarctic mass balance will not be robust until we can further characterize the short term variability within this complex ice-stream system.

\section{ACKNOWLEDGEMENTS}

Imagery for this work was provided through the Antarctic Glaciological Data Center at the US National Snow and Ice Data Center. This work was supported by the US National Science Foundation (grants OPP-0538120 to Catania, OPP9909518 to Raymond and OPP-0296099 to Hulbe). We appreciate the helpful comments from two anonymous reviewers and our scientific editor, Helen Fricker, which greatly improved the manuscript.

\section{REFERENCES}

Ackert RP, Mukhopadhyay S, Parizek BR and Borns HW (2007) Ice elevation near the West Antarctic Ice Sheet divide during the Last Glaciation. Geophys. Res. Lett., 34(21), L21506 (doi: 10.1029/2007GL031412)

Alley RB, Blankenship DD, Rooney ST and Bentley CR (1989) Sedimentation beneath ice shelves - the view from Ice Stream B. Mar. Geol., 85(2-4), 101-120

Alley RB, Anandakrishnan S, Dupont TK, Parizek BR and Pollard D (2007) Effect of sedimentation on ice-sheet grounding-line stability. Science, 315(5820), 1838-1841 (doi: 10.1126/ science.1138396)

Anandakrishnan S and Alley RB (1997) Tidal forcing of basal seismicity of Ice Stream C, West Antarctica, observed far inland. J. Geophys. Res., 102(B7), 15183-15196 (doi: 10.1029/ 97JB01073)

Anandakrishnan S, Blankenship DD, Alley RB and Stoffa PL (1998) Influence of subglacial geology on the position of a West Antarctic ice stream from seismic observations. Nature, 394(6688), 62-65 (doi: 10.1038/27889)

Anandakrishnan S, Alley RB, Jacobel RW and Conway H (2001) The flow regime of Ice Stream $\mathrm{C}$ and hypotheses concerning its recent stagnation. In Alley $\mathrm{RB}$ and Bindschadler RA eds. The West Antarctic ice sheet: behavior and environment. American 
Geophysical Union, Washington, DC, 283-296 (Antarctic Research Series 77)

Anandakrishnan S, Voigt DE, Alley RB and King MA (2003) Ice Stream $\mathrm{D}$ flow speed is strongly modulated by the tide beneath the Ross Ice Shelf. Geophys. Res. Lett., 30(7), 1361 (doi: 10.1029/2002GL016329)

Anandakrishnan S, Catania GA, Alley RB and Horgan HJ (2007) Discovery of till deposition at the grounding line of Whillans Ice Stream. Science, 315(5820), 1835-1838 (doi: 10.1126/ science.1138393)

Anderson JB, Wellner JS, Lowe AL, Mosola AB and Shipp SS (2001) The footprint of the expanded West Antarctic Ice Sheet: ice stream history and behaviour. GSA Today, 11(10), 4-9

Anderson JB, Shipp SS, Lowe AL, Wellner JS and Mosola AB (2002) The Antarctic ice sheet during the last glacial maximum and its subsequent retreat history: a review. Quat. Sci. Rev., 21(1-3), 49-70

Bamber JL, Riva REM, Vermeersen BLA and LeBrocq AM (2009) Reassessment of the potential sea-level rise from a collapse of the West Antarctic Ice Sheet. Science, 324(5929), 901-903 (doi: 10.1126/science.1169335)

Beem LH, Jezek KC and Van der Veen CJ (2010) Basal melt rates beneath Whillans Ice Stream, West Antarctica. J. Glaciol., 56(198), 647-654 (doi: 10.3189/002214310793146241)

Bell RE and 6 others (1998) Influence of subglacial geology on the onset of a West Antarctic ice stream from aerogeophysical observations. Nature, 394(6688), 58-62 (doi: 10.1038/27883)

Bentley CR (1987) Antarctic ice streams: a review. J. Geophys. Res., 92(B9), 8843-8858 (doi: 10.1029/JB092iB09p08843)

Bindschadler RA (1998) Future of the West Antarctic ice sheet. Science, 282(5388), 428-429 (doi: 10.1126/science.282. 5388.428)

Bindschadler R and Vornberger P (1998) Changes in the West Antarctic ice sheet since 1963 from declassified satellite photography. Science, 279(5351), 689-692 (doi: 10.1126/science. 279.5351.689)

Bindschadler RA, Roberts EP and Iken A (1990) Age of Crary Ice Rise, Antarctica, determined from temperature-depth profiles. Ann. Glaciol., 14, 13-16

Bindschadler RA, King MA, Alley RB, Anandakrishnan S and Padman L (2003) Tidally controlled stick-slip discharge of a West Antarctic ice stream. Science, 301(5636), 1087-1089

Bindschadler R, Vornberger P and Gray L (2005) Changes in the ice plain of Whillans Ice Stream, West Antarctica. J. Glaciol., 51(175), 620-636 (doi: 10.3189/172756505781829070)

Blankenship DD, Bentley CR, Rooney ST and Alley RB (1986) Seismic measurements reveal a saturated porous layer beneath an active Antarctic ice stream. Nature, 322(6074), 54-57 (doi: 10.1038/322054a0)

Bohlander J and Scambos TA (2007) Antarctic coastlines and grounding line derived from MODIS Mosaic of Antarctica (MOA). National Snow and Ice Data Center, Boulder, CO. Digital media: http://nsidc.org/data/moa

Bougamont M, Tulaczyk S and Joughin I (2003) Response of subglacial sediments to basal freeze-on: 2. Application in numerical modeling of the recent stoppage of Ice Stream C, West Antarctica. J. Geophys. Res., 108(B4), 2223 (doi: 10.1019/ 2002JB001936)

Brunt KM, Fricker HA, Padman L, Scambos TA and O'Neel S (2010) Mapping the grounding zone of Ross Ice Shelf, Antarctica, using ICESat laser altimetry. Ann. Glaciol., 51(55), 71-79 (doi: 10.3189/172756410791392790)

Catania GA, Conway HB, Gades AM, Raymond CF and Engelhardt H (2003) Bed reflectivity beneath inactive ice streams in West Antarctica. Ann. Glaciol., 36, 287-291 (doi: 10.3189/ 172756403781816310)

Catania GA, Conway H, Raymond CF and Scambos TA (2005) Surface morphology and internal layer stratigraphy in the downstream end of Kamb Ice Stream, West Antarctica. J. Glaciol., 51(174), 423-431 (doi: 10.3189/172756505781829142)
Catania GA, Conway H, Raymond CF and Scambos TA (2006a) Evidence for floatation or near floatation in the mouth of Kamb Ice Stream, West Antarctica, prior to stagnation. J. Geophys. Res., 111(F1), F01005 (doi: 10.1029/2005JF000355)

Catania GA, Scambos TA, Conway H and Raymond CF (2006b) Sequential stagnation of Kamb Ice Stream, West Antarctica. Geophys. Res. Lett., 33(14), L14502 (doi: 10.1029/ 2006GL026430)

Catania GA, Hulbe CL and Conway HB (2010) Grounding-line basal melt rates determined using radar-derived internal stratigraphy. J. Glaciol., 56(197), 545-554

Chen JL, Wilson CR, Blankenship D and Tapley BD (2009) Accelerated Antarctic ice loss from satellite gravity measurements. Nature Geosci., 2(12), 859-862 (doi: 10.1038/ngeo694)

Christoffersen P and Tulaczyk S (2003) Response of subglacial sediments to basal freeze-on: I. Theory and comparison to observations from beneath the West Antarctic ice sheet. J. Geophys. Res., 108(B4), 2222 (doi: 10.1029/2002JB001935)

Clarke TS, Liu C, Lord NE and Bentley CR (2000) Evidence for a recently abandoned shear margin adjacent to Ice Stream B2, Antarctica, from ice-penetrating radar measurements. J. Geophys. Res., 105(B6), 13 409-13422 (doi: 10.1029/ 2000JB900037)

Conway H, Hall BL, Denton GH, Gades AM and Waddington ED (1999) Past and future grounding-line retreat of the West Antarctic ice sheet. Science, 286(5438), 280-283 (doi: 10.1126/science.286.5438.280)

Conway H, Catania G, Raymond C, Scambos T, Engelhardt $\mathrm{H}$ and Gades A (2002) Switch of flow direction in an Antarctic ice stream. Nature, 419(6906), 465-467 (doi: 10.1038/nature01081)

Dowdeswell JA, Ottesen D, Evans J, Ó Cofaigh C and Anderson JB (2008) Submarine glacial landforms and rates of ice-stream collapse. Geology, 36(10), 819-822 (doi: 10.1130/G24808A.1)

Echelmeyer KA, Harrison WD, Larsen C and Mitchell JE (1994) The role of the margins in the dynamics of an active ice stream. J. Glaciol., 40(136), 527-538

Engelhardt H (2004) Thermal regime and dynamics of the West Antarctic ice sheet. Ann. Glaciol., 39, 85-92 (doi: 10.3189/ 172756404781814203)

Engelhardt H, Humphrey N, Kamb B and Fahnestock M (1990) Physical conditions at the base of a fast moving Antarctic ice stream. Science, 248(4951), 57-59 (doi: 10.1126/science.248. 4951.57)

Fahnestock MA, Scambos TA, Bindschadler RA and Kvaran G (2000) A millennium of variable ice flow recorded by the Ross Ice Shelf, Antarctica. J. Glaciol., 46(155), 652-664 (doi: 10.3189/172756500781832693)

Fricker HA and Padman L (2006) Ice shelf grounding zone structure from ICESat laser altimetry. Geophys. Res. Lett., 33(15), L15502 (doi: 10.1029/2006GL026907)

Fricker HA and Scambos T (2009) Connected subglacial lake activity on lower Mercer and Whillans Ice Streams, West Antarctica, 2003-2008. J. Glaciol., 55(190), 303-315 (doi: 10.3189/002214309788608813)

Fricker HA, Scambos T, Bindschadler R and Padman L (2007) An active subglacial water system in West Antarctica mapped from space. Science, 315(5818), 1544-1548 (doi: 10.1126/ science.1136897)

Glasser NF and Gudmundsson GH (2011) Longitudinal surface structures (flowstripes) on Antarctic glaciers. Cryos. Discuss., 5(6), 3085-3112 (doi: 10.5194/tcd-5-3085-2011)

Gray L, Joughin I, Tulaczyk S, Spikes VB, Bindschadler R and Jezek K (2005) Evidence for subglacial water transport in the West Antarctic Ice Sheet through three-dimensional satellite radar interferometry. Geophys. Res. Lett., 32(3), L03501 (doi: 10.1029/2004GL021387)

Gudmundsson GH, Raymond CF and Bindschadler R (1998) The origin and longevity of flow stripes on Antarctic ice streams. Ann. Glaciol., 27, 145-152 
Haran T, Bohlander J, Scambos T, Painter T and Fahnestock $M$ (2006) MODIS mosaic of Antarctica (MOA) image map. National Snow and Ice Data Center, Boulder, CO. Digital media: http://nsidc.org/data/moa/

Horgan HJ and Anandakrishnan S (2006) Static grounding lines and dynamic ice streams: evidence from the Siple Coast, West Antarctica. Geophys. Res. Lett., 33(18), L18502 (doi: 10.1029/ 2006GL027091)

Hulbe CL and Fahnestock MA (2004) West Antarctic ice-stream discharge variability: mechanism, controls and pattern of grounding-line retreat. J. Glaciol., 50(171), 471-484 (doi: 10.3189/172756504781829738)

Hulbe C and Fahnestock M (2007) Century-scale discharge stagnation and reactivation of the Ross ice streams, West Antarctica. J. Geophys. Res., 112(F3), F03S27 (doi: 10.1029/ 2006JF000603)

Jacobel RW and Gades AM (1995) Radar observations of a relict ice-stream margin traversing Siple Dome, Antarctica. Antarct. J. US, 30(5), 89-91

Jenkins A and 6 others (2010) Observations beneath Pine Island Glacier in West Antarctica and implications for its retreat. Nature Geosci., 3(7), 468-472 (doi: 10.1038/ngeo890)

Joughin I and Tulaczyk S (2002) Positive mass balance of the Ross ice streams, West Antarctica. Science, 295(5554), 476-480 (doi: 10.1126/science.1066875)

Joughin I and 7 others (1999) Tributaries of West Antarctic ice streams revealed by RADARSAT interferometry. Science, 286(5438), 283-286 (doi: 10.1126/science.286.5438.283)

Joughin I, Tulaczyk S, Bindschadler RA and Price S (2002) Changes in West Antarctic ice stream velocities: observation and analysis. J. Geophys. Res., 107(B11), 2289 (doi: 10.1029/2001JB001029)

Joughin IR, Tulaczyk S and Engelhardt HF (2003) Basal melt beneath Whillans Ice Stream and Ice Streams A and C, West Antarctica. Ann. Glaciol., 36, 257-262 (doi: 10.3189/ 172756403781816130)

Joughin I and 10 others (2005) Continued deceleration of Whillans Ice Stream, West Antarctica. Geophys. Res. Lett., 32(22), L22501 (doi: 10.1029/2005GL024319)

Kim W, Paola C, Swenson JB and Voller VR (2006) Shoreline response to autogenic processes of sediment storage and release in the fluvial system. J. Geophys. Res., 111(F4), F04013 (doi: 10.1029/2006JF000470)

Le Brocq AM, Payne AJ and Vieli A (2010) An improved Antarctic dataset for high resolution numerical ice sheet models (ALBMAP v1). Earth Syst. Sci. Data, 2(2), 247-260 (doi: 10.5194/essdd-3195-2010)

Lythe MB, Vaughan DG and BEDMAP consortium (2001) BEDMAP: a new ice thickness and subglacial topographic model of Antarctica. J. Geophys. Res., 106(B6), 11335-11351 (doi: 10.1029/2000JB900449)

MacAyeal DR (1992) Irregular oscillations of the West Antarctic ice sheet. Nature, 359(6390), 29-32 (doi: 10.1038/359029a0)

Mosola AB and Anderson JB (2006) Expansion and rapid retreat of the West Antarctic Ice Sheet in eastern Ross Sea: possible consequence of over-extended ice streams? Quat. Sci. Rev., 25(17-18), 2177-2196

Nereson NA and Raymond CF (2001) The elevation history of ice streams and the spatial accumulation pattern along the Siple Coast of West Antarctica inferred from ground-based radar data from three inter-ice-stream ridges. J. Glaciol., 47(157), 303-313 (doi: 10.3189/172756501781832197)

Nereson NA, Raymond CF, Waddington ED and Jacobel RW (1998) Migration of the Siple Dome ice divide, West Antarctica. J. Glaciol., 44(148), 643-652

Parizek BR, Alley RB and Hulbe CL (2003) Subglacial thermal balance permits ongoing grounding-line retreat along the Siple Coast of West Antarctica. Ann. Glaciol., 36, 251-256 (doi: 10.3189/172756403781816167)

Payne AJ (1998) Dynamics of the Siple Coast ice streams, West Antarctica: results from a thermomechanical ice sheet model.
Geophys. Res. Lett., 25(16), 3173-3176 (doi: 10.1029/ 98GL52327)

Payne AJ and Dongelmans PW (1997) Self-organization in the thermomechanical flow of ice sheets. J. Geophys. Res., 102(B6), 12 219-12 233 (doi: 10.1029/97JB00513)

Price SF, Bindschadler RA, Hulbe CL and Joughin IR (2001) Poststagnation behavior in the upstream regions of Ice Stream C, West Antarctica. J. Glaciol., 47(157), 283-294 (doi: 10.3189/ 172756501781832232)

Price SF, Conway $\mathrm{H}$ and Waddington ED (2007) Evidence for late Pleistocene thinning of Siple Dome, West Antarctica. J. Geophys. Res., 112(F3), F03021 (doi: 10.1029/2006JF000725)

Pritchard HD, Arthern RJ, Vaughan DG and Edwards LA (2009) Extensive dynamic thinning on the margins of the Greenland and Antarctic ice sheets. Nature, 461(7266), 971-975 (doi: 10.1038/nature08471)

Retzlaff R and Bentley CR (1993) Timing of stagnation of Ice Stream C, West Antarctica, from short-pulse radar studies of buried surface crevasses. J. Glaciol., 39(133), 553-561

Rippin DM, Siegert MJ and Bamber JL (2003) The englacial stratigraphy of Wilkes Land, East Antarctica, as revealed by internal radio-echo sounding layering, and its relationship with balance velocities. Ann. Glaciol., 36, 189-196 (doi: 10.3189/ 172756403781816356)

Rippin DM, Siegert MJ, Bamber JL, Vaughan DG and Corr HFJ (2006) Switch-off of a major enhanced ice flow unit in East Antarctica. Geophys. Res. Lett., 33(15), L15501 (doi: 10.1029/ 2006GL026648)

Scambos TA and Bindschadler RA (1991) Feature maps of Ice Streams C, D and E, West Antarctica. Antarct. J. US, 26(5), 312-314

Scambos TA and Nereson NA (1995) Satellite image and GPS study of the morphology of Siple Dome, Antarctica. Antarct. J. US, 30(5), 87-89

Scambos TA, Haran TM, Fahnestock MA, Painter TH and Bohlander J (2007) MODIS-based Mosaic of Antarctica (MOA) data sets: continent-wide surface morphology and snow grain size. Remote Sens. Environ., 111(2-3), 242-257 (doi: 10.1016/ j.rse.2006.12.020)

Schoof C (2007) Ice sheet grounding line dynamics: steady states, stability, and hysteresis. J. Geophys. Res., 112(F3), F03S28 (doi: 10.1029/2006JF000664)

Sergienko O, MacAyeal DR and Bindschadler RA (2009) Stick-slip behavior of ice streams: modeling investigations. Ann. Glaciol., 50(52), 87-94 (doi: 10.3189/172756409789624274)

Smith AM (1996) Ice shelf basal melting at the grounding line, measured by seismic observations. J. Geophys. Res., 101(C10), $22749-22755$

Smith BE, Lord NE and Bentley CR (2002) Crevasse ages on the northern margin of Ice Stream C, West Antarctica. Ann. Glaciol., 34, 209-216 (doi: 10.3189/172756402781817932)

Smith BE, Bentley CR and Raymond CF (2005) Recent elevation changes on the ice streams and ridges of the Ross Embayment from ICESat crossovers. Geophys. Res. Lett., 32(21), L21S09 (doi: 10.1029/2005GL024365)

Stearns LA, Jezek KC and Van der Veen CJ (2005) Decadal-scale variations in ice flow along Whillans Ice Stream and its tributaries, West Antarctica. J. Glaciol., 51(172), 147-157 (doi: 10.3189/172756505781829610)

Stearns LA, Smith BE and Hamilton GS (2008) Increased flow speed on a large East Antarctic outlet glacier caused by subglacial floods. Nature Geosci., 1(12), 827-831 (doi: 10.1038 /ngeo356)

Stone JO and 6 others (2003) Holocene deglaciation of Marie Byrd Land, West Antarctica. Science, 299(5603), 99-102 (doi: 10.1126/science.1077998)

Thoma M, Jenkins A, Holland D and Jacobs S (2008) Modelling circumpolar deep water intrusions on the Amundsen Sea continental shelf, Antarctica. Geophys. Res. Lett., 35(18), L18602 (doi: 10.1029/2008GL034939) 
Thomas RH, MacAyeal DR, Eilers DH and Gaylord DR (1984) Glaciological studies on the Ross Ice Shelf, Antarctica, 19731978. In Hayes D and Bentley CR eds. The Ross Ice Shelf: glaciology and geophysics. American Geophysical Union, Washington, DC, 21-53 (Antarctic Research Series 42)

Thomas RH, Stephenson SN, Bindschadler RA, Shabtaie S and Bentley CR (1988) Thinning and grounding-line retreat on Ross Ice Shelf, Antarctica. Ann. Glaciol., 11, 165-172

Tulaczyk SM, Kamb B and Engelhardt HF (2000) Basal mechanics of Ice Stream B, West Antarctica. II. Undrained-plastic-bed model. J. Geophys. Res., 105(B1), 483-494 (doi: 10.1029/ 1999JB900328)

Uratsuka S, Nishio F and Mae S (1996) Internal and basal ice changes near grounding line derived from radio-echo sounding. J. Glaciol., 42(140), 103-109

Weertman J (1974) Stability of the junction of an ice sheet and an ice shelf. J. Glaciol., 13(67), 3-11

Wingham DJ, Siegert MJ, Shepherd A and Muir AS (2006) Rapid discharge connects Antarctic subglacial lakes. Nature, 440(7087), 1033-1036 (doi: 10.1038/nature04660)

MS received 17 October 2011 and accepted in revised form 25 February 2012 